\title{
Expression artistique et thérapeutique
}

I

1 y a quelques années, j’ai entendu parler d'une statistique qui m'a cho-quée; En 13 semaines, 12 pompiers canadiens s'étaient suicidés. À ce moment, je savais ce qu'était le trouble du stress post-traumatique (TSPT) et ses effets, mais je ne savais pas à quel point il pouvait être fatal. Une semaine plus tard, mon peloton a participé à une lecture au sujet des signes, des symptômes et des causes associées au TSPT. Pendant que j'écoutais le conférencier, j’ai remarqué que je subissais une partie de ses signes et symptômes. Est-ce que je souffrais aussi de TSPT ? C'est impossible ! Problèmes de sommeil, dépression, agitation excessive et en retrait, faisaient partie des symptômes que je reconnaissais en moi.

Le conférencier a mentionné que plusieurs de ses clients étaient surpris de savoir qu'ils avaient été diagnostiqués comme souffrant d'un TSPT, et beaucoup d'entre eux pensaient qu'ils n'avaient pas d'événements " déclencheurs ». Je devais savoir. J'ai pris un rendez-vous avez un psychologue et j'ai fait quelques séances. Il m'a dit que j'avais une réaction normale à des expériences anormales. Je lui ai demandé si je souffrais de TSPT. Il m’a répondu : «Oui, et toute personne travaillant dans votre domaine, avec la même expérience et le même temps passé à faire ce travail, aurait également des signes similaires de TSPT ». Heureusement, ma condition n'est pas aussi débilitante que celle d'autres personnes souffrant du même trouble.

Mon trouble provient d'une accumulation de plusieurs événements plutôt que d'une seule expérience spécifique. Je traite mes pensées en recréant des images dans ma tête et en les reproduisant numériquement. Mes créations artistiques sont les résultats de mon processus de guérison. Quand j'ai commencé à afficher mes images en ligne, j'ai été très surpris par le nombre incroyable de commentaires que j’ai reçus. On aurait dit que j'avais touché une corde sensible dans ma communauté des travailleurs et travailleuses d'urgence. Tellement de personnes se sont retrouvées dans mes créations artistiques, et même certains m'ont dit qu'ils s'étaient mis à pleurer après avoir vu les images. J'ai été très touché par l'attention internationale de mes créations artistiques, mais ce qui est encore plus gratifiant est la communauté qui s'est créée grâce à cela.

J'ai un nombre impressionnant d'événements indésirables qui envahissent ma tête. J'arrive à les contrôler durant la journée mais, la nuit, ils entrent dans mes rêves et font ce qu'ils veulent. La motivation de mes créations artistiques est en rapport avec ces nombreux événements et ces appels auxquels j'ai participé. Souvent, ils entrent dans les salles d'urgence de ma communauté et je suis obligé de partager ces appels cauchemardesques avec le personnel qui travaille ici. Il y a eu tant d'urgences marquantes auxquelles j'ai participé avec les infirmiers/infirmières des SU. Au début de ma carrière professionnel, j'avais hâte de vivre ces événements, mais maintenant ils me hantent. Je me demande si ces moments ont également impacté mes amis infirmiers/infirmières de la même façon.

Je crée mes images en choisissant d'abord un de ces événements évasifs présents dans ma tête. Je mets en scène l'appel et je capture l'image en utilisant des collègues de travail et des acteurs. Quand je travaille sur l'image, je fais ressortir les émotions que j'ai ressenties lors de l'appel au lieu de décrire ce que je voyais, puis je dessine numériquement au-dessus de l'image que j'ai mise en scène. Il me faut environ une semaine pour terminer chaque pièce et quand j'ai terminé, cet envahisseur intérieur présent dans ma tête devient cette image sans vie et unidimensionnel sur l'écran de mon ordinateur. C'est toujours un peu effrayant de partager mes œuvres, et j'en ai plusieurs que je n'ai jamais présentées. Je n'ai jamais imaginé que d'autres personnes allaient intégrer leurs propres expériences à mes créations artistiques et s'y connecter de manière aussi forte.

Tellement de premiers intervenants me contactent et n'ont pas l'aide qu'ils devraient recevoir, et certains ne sont même pas soutenus par leurs employeurs quand il s'agit de santé mentale. Tous les jours, de nombreuses personnes me parlent de leurs expériences avec les services de santé mentale et d'urgence. Il y a tellement de personnes qui pensent comme nous, et nous ne sommes pas les seuls à ressentir cela. D'autres ont réussi à recevoir de l'aide dont ils avaient tellement besoin et se sentent mentalement mieux maintenant. Voici un récent message que j'ai reçu de la part d'un ambulancier aux États-Unis.

« Bonjour M. DanSun. Je voulais vous remercier pour vos créations artistiques et vous faire savoir qu'elles ont fortement influencé ma vie ». Il y a un an, je me suis retrouvé dans un sombre monde intérieur. J'étais à l'école d'ambulancier et je portais avec moi de nombreux démons qui s'étaient accrochés à moi en raison de mes nombreuses expériences sur la route. J'ai vu vos créations artistiques et lu certains des commentaires, et j'ai vite réalisé que je n'étais pas le seul à ressentir cela. J'ai vraiment eu l'impression que je n'étais plus seul et que ce que je ressentais était normal. J'ai demandé de l'aide et j'ai reçu le traitement dont j'avais tant besoin. La nuit dernière, j'ai réussi à sauver une vie pour la première fois au cours d'un arrêt cardiaque. C'était mon premier appel en tant qu'ambulancier en chef. Merci de m'avoir aidé à arriver là où j'en suis en ayant réussi à changer la vie de cet homme. Continuez à faire ce que vous faites $\gg$.

Les personnes spécialisées en santé mental pour les travailleurs et travailleuses d'urgence sont là pour vous aider. Beaucoup d'entre nous pensent qu'il n'y a pas de sortie à ce cauchemar, mais l'aide est là.

Certaines personnes ont critiqué mes œuvres en me disant qu'elles ne montrent que le côté négatif des services d'urgence et que mon travail est triste et déprimant. Je leur réponds en leur disant que j'essaye de sensibiliser les personnes à la santé mentale et au PSPT par mes créations artistiques en montrant les situations intenses auxquelles nous faisons face. Être un travailleur d'urgence est quelque chose d'incroyable et je le recommande à 
quiconque car il n'y a pas beaucoup d'autres emplois qui vous permettent de faire une réelle différence dans la vie d'une personne.

Merci à toutes et à tous pour votre soutien continu. Restez prudents et aidonsnous les uns les autres.

\section{Respectueusement, \\ Daniel Sundahl \\ DanSun Photo Art \\ www.dansunphotoart.com}

Note de la rédaction: Si vous êtes victime de stress à cause d'un traumatisme que vous avez subi, n'hésitez pas à communiquer. Vous n'êtes pas seuls. Des ressources sont disponibles dans votre lieu de travail par le biais de programme d'aide aux employés et votre fournisseur de soins primaires. Vous pouvez contacter en tout temps le Service Info Santé mentale Ontario au 1-866-531-2600. Les informations et les ressources sur le TSPT sont disponibles par le biais de la PTSD Association of
Canada (www.ptsdassociation.com). Si vous avez un intérêt professionnel dans les soins associés au TSPT, l'Université Simon Fraser de Colombie-Britannique a un programme en ligne à temps partiel qui se nomme « First Responders Trauma Prevention and Recovery Certificate » (www.sfu.ca).

\section{NCAC report}

$\mathrm{F}$ all always reminds me of the beginning of a new school year and even though I am no longer in school, somehow I have this renewed sense of purpose; a time to start afresh, to make "lists" of things to do (which we have put off during those lazy days of summer). Lautomne me rappelle toujours le début d'une nouvelle année scolaire. Je ne suis pas à l'école mais je pense que je devrais être plus organisé comme quand j'étais étudiant.

So, it seems appropriate to be asked to do a "report" of NCAC's activities for the journal. On ma demandé de faire un résumé des activités de la NCAC. It also seems appropriate that this should follow Thanksgiving and Emergency Nursing Week-where we reflect on how thankful we are for family, friends and country and where we celebrate our brothers and sisters in this incredible profession of ours. Je voudrais tout d'abord vous dire Joyeux Thanksgiving et Bonne Semaine des soins infirmiers d'urgence à tous mes collègues infirmiers.

In the last journal, you met our current NCAC members: Denis Bouchard, our French rep; Dawn Paterson, our Western rep; Sharon Ramagnano, our Central rep; Maureen Doody, our Eastern rep; Val Lamb, our EPICC rep and yours truly, the Chairperson of NCAC. At the end of May, we all met for the first time as the National Course Administrative Committee at the NENA Conference in beautiful Charlottetown, PEI. I was humbled and inspired to be part of this dynamic group of nurses. The leadership and vision of these incredible nurses is what drives our committee. We have a shared commitment and value of

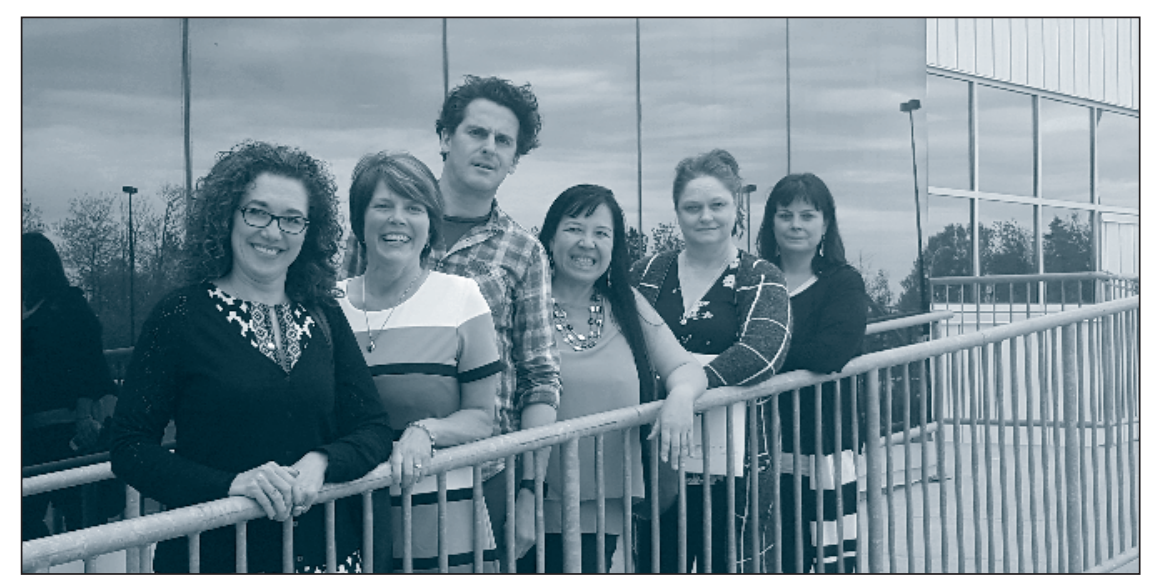

NCAC teaching EPICC in Charlottetown! From left to right: Maureen Doody, Val Lamb, Denis Bouchard, Monique McLaughlin, Sharon Ramagnano and Dawn Paterson.

connecting with nurses nationally and to support access to quality nursing education. We are concerned about the barriers (financial, language and geographical) that prevent nurses from accessing education. Les infirmières de ce comité représentent le meilleur des soins infirmiers à l'échelle nationale. We are voicing those concerns at the national table as we work to overcome those barriers. We are currently in negotiations with ENA around the contract to provide TNCC and ENPC in Canada. We are still advocating for French translation in all of our educational materials. We are supporting the rollout of EPICC nationally, as we feel EPICC provides many solutions to some of those barriers to education. For anyone interested in knowing more about EPICC, feel free to check out the website epicclearning.ca. Nous travaillons sur le contrat avec ENA pour TNCC et ENPC. Nous aidons à soutenir l'éducation EPICC. Nous parlons pour la traduction française.
Our Facebook page TNCC ENPC EPICC (NCAC) is a wonderful opportunity for us to share articles, podcasts, etc., to motivate nurses in lifelong learning. It is also a great networking for nurses to meet nationally. We encourage you to post photos of your courses, share articles, podcasts on the Facebook page. We love hearing from you. Connect with us on Facebook. Share your photos of your courses, interesting articles (yes in French). Please also contact as at courses@nena.ca (this is our e-mail address and we will definitely respond to your questions). We need to hear your concerns, questions and comments. We want to be a responsive committee to you. Nous voulons entendre vos pensées et vos questions. Notre comité est là pour servir les infirmières.

\footnotetext{
"The best way to find yourself is to lose yourself in the service of others."

-Mahatma Ghandi
}

\section{Monique McLaughlin \\ Chairperson NCAC}

